\title{
On Immanuel Kant's Concept of Duty
}

\author{
Kow Kwegya Amissah Abraham \\ http://dx.doi./org/10.4314/ujah.v20i2.2
}

\begin{abstract}
Central to the philosophical discourse on duty is its ontology, the sanctioning entity, and what legitimises an act to assume the status of duty. Kant conceives of duty to involve the recognition of, and submission to the moral law. The focus of this work is to critically interrogate the Kantian conception of duty normatively and the veracity of its application when the conceptualisation assumes practical posture. This is to understand as to whether acting from duty on the one hand, and the universalizability of a moral law according to which a moral agent ought to act on the other hand, guarantees that one acts without any consideration, but for duty. The import is to offer a pragmatic perspective to understanding Kant's conception and to realign his metaphysical conceptualisation of duty within human capabilities. We do this with the position that duty must be within the practical capabilities of humans in moral decision-making.
\end{abstract}

Keywords: Deontology, Duty, Kantian, Moral Law.

\section{Introduction}

The concept of duty is seen as one of the pillars in Kant's ethics. In fact, Kant's exposition on duty clearly defines why his ethics is deontological. After carefully laying bare what he meant by the good will which is conceived as the highest good in his deontology, Kant moves to explain how this good will is to be used in the light of what duty is. In his Groundwork of the 
Metaphysics of Morals (1998), Kant alludes to the view that since under human conditions we struggle against unruly impulses and desires, the only way a good will is manifested is in acting for the sake of duty. Thus, to Kant a human action is morally good, not because it is done from immediate inclination - still less because it is done from self-interest - but because it is done for the sake of duty (Kant, 1959).

The deontological position espoused by Kant revolutionised the ethical discourse in his time, thus several scholars added further analysis to his position. Lillie (1966) makes an exposition on Kant's deontology with the claim that for a practical estimate of the desirability of one action rather than another to be achieved, there is the need to take into account, not only the pleasantness of the consequences of the action, but also the probability of these consequences actually occurring. He argues further that Kant's dutyhas been conceptualised by some philosophers as a duty of perfect obligation and its meaning is mostly misconstrued. This is because when we refer to a duty of perfect obligation we sometimes mean that it can be expressed in a definite law like you ought to pay your debts. At other times, it is a duty, which holds unconditionally in any, circumstances whatever, such as the obligation to be honest. For Birsch (2002), Kant's claim that moral laws are perceived as universal commands, the basis upon which it becomes our duty, is not necessarily the case. This is because such conception reneges to the problem of descriptions for actions which relates to the procedure for creating moral laws. By this a person must be able to identify an action and then decide on the rule that guides the action without recourse to instances when moral laws can conflict and so require exceptions thereof. In a likely manner, Ozumba (2002) also offers a useful insight into Kant's ethics, where he reiterated the point that Kant 
sees duty and obligation as the necessity for acting out of respect for the moral law. He further asserted that, the motive of the will, in Kant's ethics, is good only if this motive necessarily emanates from acting from duty.

In his contribution, Cooke (1974) is of the view that an exclusive concentration on the Groundwork or the Critique can easily lead to a misunderstanding of the basic thrust of Kantian deontology. This is because while it is certainly true that Kant emphasised the categorical character of moral obligation as no one had previously, still, Kantian ethics is in a fundamental sense, a teleological ethic, concerned above all with ends of action, human fulfilment and happiness. Cooke, thus, avers that;

While Kant held that moral effort is of supreme worth and while he believed that particular duties were sometime derivable from a purely formal principle, he always held that the pursuit of morality would be senseless if it was not aimed at the realisation of one's natural perfections in a harmonious community. His main ethical concern was with human fulfilment and the condition of its attainment (Cooke, 1974:48).

Analysing Kant's ethics this way, Cooke (1974) stresses that Kant's deontology has affinities with a natural law view of morality. In principle, the arguments he puts across, directly speaks with the position Kant espouses, we however think that Kant's deontology will be more appealing if we look at it from the perspective of the way humans behave and the influences of human choices.

Field (1966) also argues that Kant's ethics started with several assumptions about what is right or wrong. For instance, there was the assumption that if there is a moral law at all then it 
must be absolute and universal. Again, if a thing is really good, then, it must be good in itself. There also was the assumption that the rightness or wrongness of an action can neither depend on what we want nor the actual results of the action. Field (1966) further makes the claim that Kant assumed that the essence of goodness and the moral law are to be deduced from the notion that whenever we act we must also have will that our action becomes a universal law. Here, Field (1966) seems to have premised Kant's position on a wrong proposition especially when Kant rather proceeded with the idea that moral assessment ought to be grounded in reason in order to make it less vulnerable to critiques. On this bases, the Groundwork rests on the premise that only an a priori theory of the foundations of morality can account for the unrelenting normative force of moral principles (Kant, 1998).

\section{The ontology of Kant's concept of duty}

An action is prescriptive when it requires or makes it imperative that moral agents perform it. In our general daily parlance, humans, in one way or the other, have actions which are our requirement to perform. These actions could be prescribed by either the society, a group of individuals or the individual herself. Generally, every human actions is motivated by certain factors. Thus no thought arises out of a vacuum. The motive behind every human action can either be consequential motive or deontological. It is thus not inconceivable to assess morality based on motive. We establish that motive is not only the preserve of deontologists. The point of departure between consequentialist and deontologists is with the nature of motive, and further where to place moral praise and blame when assessing an action that has a moral content.

In departing from the consequentialist approach to moral assessment, Kant seeks to establish a criterion for moral 
assessment a priori. Indeed, when an action that has a moral content is assessed based on the motive of duty, it can be conceived that the moral agent can be held morally responsible, and justifiably so, for his actions and inactions. This is because, intent of duty is a priori, and it is a rational activity to which the moral agent has control over. In other words, one becomes fully responsible for actions that she chooses as a matter of full thought. For instance, a mad person, clinically pronounced so after committing a crime, is likely to escape punishment, rather be detained in a psychiatric hospital where she should actually be prior to the committal of the crime. This means that a moral responsibility is anchored on the freedom of choice of the moral agent. On this basis, since moral agents, to a very large extent, have control over their intents than the end results of their action, then moral assessment must be based on the content of their intent therein.

In examining the content of the intent to which moral assessment is made, Kant postulates that it be an intent of duty. This is to conscript moral agents to performing those actions which we do not want to perform. Thus fundamental to Kant's deontology is the belief that morality is a matter of following absolute rules. Absolute rules are rules that admit of no exceptions and must be followed in all instances (Williams, 1972). Again, they are maxims done out of duty and it is what carries moral worth. Moral obligations, by contrast, do not depend on our having particular desires. Moral requirements are categorical, that is, they have the form "you ought to do such and such." Thus so, just as hypothetical 'oughts' are possible because we have desires, categorical 'oughts' are binding on rational agents simply because they are rational. 
In his analysis of Kant's position, Sandel (2010) observes that the motive that confers moral worth on an action is the motive of duty, by which Kant means doing the right thing for the right reason. This means that when we assess the moral worth of an action, we assess the motive from which it's done, not the consequences it produces. In this vein, Kant contrasts "motives of inclination" with the "motive of duty" and insists that only actions performed out of the motive of duty have moral worth.

For Korsgaard (2009), Kant thinks that the motivation to any action involves two factors, an incentive and a principle or maxim. On this basis, moral agents are subject to an incentive upon being aware of certain features that make an object attractive. However, such appeals by the feature seldom make an action has a moral content. Rather those actions which satisfy the principle and pass the universalisability test. In the Groundwork for the Metaphysics of Morals there are duties to the self and duties to others as well as perfect or strict and imperfect or wide duties; and they are mentioned first within the respective categories of strict and wide duty (Kant, 1998). To illustrate the ontology duty, Kant provides some examples such as duty to preserve one's life, be beneficent or kind, etc, (Kant 1994).

Generally, Kant is seen to have made three propositions about duty, the first one states that an action is not regarded as morally good if it is done solely out of self-interest(Kant, 1998). This is so even if the action accords with duty and is in that sense right. To determine the moral worth of an action, it is important to isolate the motives upon which the action is performed. Here, we must first consider an action done solely out of impulse and desire and not out of duty and those done out of duty and not out of impulse or desire. By doing this, Kant believes that we are bound to find out that an action done solely out of natural sympathy may 
be right and praiseworthy but that it has no distinctive moral worth. Thus, the goodness shown in helping others is all the more conspicuous if a man does this for the sake of duty at a time when he is fully occupied with his own troubles and when he is not impelled to do so by his natural inclination to some interest (von Wright, 1963).

To this, Paton (1964) shares the view that Kant's doctrine would be absurd if it meant that the presence of natural inclination to good actions does not make that action morally worthy. He says that a man shows moral worth if he does good, not from inclination but from duty. Paton (1964) further believes that Kant is here contrasting two motives taken in isolation in order to find out which of them is the source of moral worth. Kant would have avoided the ambiguity if he had said that a man shows moral worth, not in doing good from inclination, but in doing it for the sake of duty. The assumption that we see Kant carrying here is that, if an action is to be morally good, the motive of duty must by itself be sufficient to determine it. We, however, think that Kant believes generous inclinations help in doing good actions and for this reason it is our duty to cultivate them. This view is shared by Paton (1964) when he observes of Kant that we have at least an indirect duty to seek our own happiness.

The second proposition from Kant which is also called the formal principle of duty states that an action done from duty has its moral worth not from the results it attains or seeks to attain, but from a formal principle or maxim - the principle of doing one's duty whatever that duty may be (Kant, 1998). In this context it is important to explain what is meant by 'maxim'. A maxim is a personal principle upon which we act. Kant (1959) calls it a subjective principle; this is because it is a principle on which rational agents do act. For Kant, the maxim that carries a moral 
worth is that based on the principle of doing one's duty. Such a maxim is not one that is aimed at satisfying particular desires or attaining particular results. He calls such a maxim (that which carries moral worth) a formal maxim (Louden, 2000). Thus, to act for the sake of duty is to act on a formal maxim irrespective of all external factors like desires. A man's actions are morally good when he adopts or rejects material maxims of any proposed action according as it harmonizes or conflicts with the formal maxim of doing his duty for its own sake (Kempt, 1968).

The third proposition is that duty is the necessity to act out of reverence for the law (Kant, 1959). The meaning we derive from this proposition is that to act on the maxim of doing one's duty for its own sake is to act out of reverence for the law. Further explanation reveals another fact; Kant appears to hold that if a maxim of a morally good action is a formal one, then, it must be a maxim of acting reasonably. That is, it must be a maxim of acting on a law valid for all rational beings and is independent of any desires. Kant stresses on this because he naturally sees humans as fallible and as such a law must appear to us as a law of duty and such an imposed law must consequently incite a feeling of fear or a feeling analogous to inclination and this complex feeling is what Kant referred to as reverence. This means that so far as the motive of a good action is to be found in feeling, we must say that a morally good action is one which is done out of reverence for the law and that is what gives it a unique and unconditional value (Paton, 1964).

Kant (1994) also states that an action performed from duty does not have its moral worth in the purpose for which it is to be achieved, rather in the maxim by which it determines. That is, an action has moral worth not because of the value of consequences but mainly because of the principle involved. In other words, what 
actually results from an action is not morally significant since the whole moral value of an action rests in the formal character of the principle which determines the action. This implies that when the will is itself determined by nothing but the moral law, it is a good will, and when an act is determined by nothing but respect for duty, it is also determined by respect for the moral law. He again stresses the point that it is not the results of what is done that affects the moral worth of an action, rather, the whole value of an action is dependent upon respect for and deliberate obedience to the moral law (Kant, 2013). Ross (1962)re-echoes Kant's position with the assertion that our duty is not to perform those actions with the aim of producing certain results.

Duty as an absolute rule

For Kant (1998), the concept of duty is embedded in the concept of the good will; this is because acting out of the good will is the true performance of our duty. In other words, it is our duty to act out of the good will and not because of any end to be achieved. So he further proposes that we consider only the special cases of the good will. That is, cases where the good will must overcome certain subjective limitations and hindrances (Kant, 1959). And so,acting from duty is not a necessary condition for possessing a good will, this is because a will can be good even when it does not act from duty.

It is important at this point to make a distinction between acting in conformity with duty and acting from duty. An action conforms to duty just in case it is compatible with what duty requires. In other words, for an action to conform to duty it is only necessary that the action be compatible with the requirements of duty no matter what the motive is for performing that action. For instance, duty to be honest when selling conforms to duty even if one is motivated to do so out of rational self-interest rather than 
respect for the moral law. This seems to be in line with the ordinary conception of what duty is. Thus, in our ordinary moral lives, there is no distinction between acting from duty and acting in conformity with duty. We generally accept, sometimes consciously, an action that merely conforms to duty. Kant (2013), however, focuses on actions that emanate from duty and considers only those ones as moral.

We can, however, readily distinguish whether an action that agrees with duty is actually done from duty or from a selfish view. It must be noted that there is always the difficulty in making some of those distinctions when an action accords with duty. For instance, to use Kant's own example, it is always a matter of duty that a dealer should not over-charge an inexperienced purchaser and whenever there is much commerce the prudent tradesman does not overcharge but keeps a fixed price for everyone so that even a child might be able to buy from him just like any other. The implication is that people must be honestly served, but this is not enough to make us believe that the tradesman has acted from duty and from the principles of honesty. This is because his own advantage required it and it would not be out of the question, in this case, to suppose that he might, rather have a direct inclination in favour of the buyers; so that from love he should give no advantage to one over another. In this case, Kant (2013) would say that the dealer did not act from duty or from inclination to act from what duty requires but merely with a selfish interest.

In furtherance, Kant (2013) claims that only actions done from duty have moral worth or moral content. The moral worth of an action, however, goes beyond the value that would merit moral approval.It is more than its compatibility with the requirements of duty and also consists in its being motivated in the right sort of way (Shirk, 1965). Specifically, an action only has moral worth if 
it is done from duty. We have a duty to cultivate other things such as love, sympathy and other desires that make it easier to do our duty, however, he denies that actions done from duty are done with repugnance (Urmson: 1967). This is because he thinks that when we act only in conformity to duty, it will reveal that we have a hidden hatred for the law, which also contravenes our acting from the good will. In other words, the moral worth of the action does not depend upon the realization of the object of the action but merely upon the principle of volition in accordance with which the action is done. Here, Kant (1964) seems to claim that:

1. The moral worth of an action done from duty does not depend on what it accomplishes.

2. The moral worth of an action done from duty depends merely on its maxim (Zink, 1962).

A searchlight on moral duty reveals that one way or the other, every rational individual experiences innate moral duty. Whenever we violate a moral duty, our conscience and feelings of guilt and shame tell us. For Kant, moral duty could be revealed to us through reason in the objective sense (Kant, 1959). To act morally is to perform one's duty and one's duty is to obey the innate moral laws. These laws according to Kant are absolute in every sense. Kant's concept of duty can therefore be summarized as:

1. To act from duty is to necessarily act according as the moral law stipulates and with reverence to such law.

2. For an action to have moral worth, that particular action must be done from duty.

3. The Good will is responsible for making rational agents perform actions out of duty. 
With the arguments so far adduced, can we say that when an action is performed out of duty and then attains a moral worth as Kant claims, that maxim becomes absolute? For instance, if an individual's action fully satisfied the universalisability test and was especially performed out of a moral duty, could we, by this, claim that those actions do become an absolute rule?

Critically analysing the concept of duty, one finds some difficulties that pertain even in our everyday life. Ross (1975) outlines various duties that he calls prima facie and each of which is to be given independent weight. They are fidelity, reparation, gratitude, beneficence, non-maleficence and self-improvement (Ross, 1975). He then claims that if an act falls under one and only one of these duties, it ought to be performed. However, an act might fall under two or more duties. For instance, I may owe a debt of gratitude to someone who once helped me but beneficence will be more useful at that particular moment if I helped others in greater need. Here, Ross seeks to answer the question of what is my duty with his list of prima facie duties since Kant was criticized for not letting us know what constitutes our duty. Ross, however, chose the word prima facie rather than absolute. This is because he reasoned that each duty can be overridden if it conflicts with a more stringent duty. Much as we may agree with Ross to some extent, we also think that the duties that he outlined does not capture all necessary actions in human endeavours and so not too important. However, duties, whichever category they fall under have the tendency to clash with other duties and it will not be important for anyone to start looking through such criteria. All one has to do is to consider those duties that have clashed with reference to their anticipated consequences.

Miller (1995) thinks that, for Kant, only the unconditional 'ought' is the moral ought. This is because morality must be 
necessary and universal; that is, it must be absolutely binding on everyone alike and so whatever situation one finds oneself, one ought to act in accordance with the requirement of the law. The implication is that moral acts are to be accomplished irrespective of other considerations such as merit and reward. Thus, Miller suggests that this morality must be "binding" and "universal" (Miller, 1995), and that is the position of Kant. When one understands the departure of a moral act from its consequences, then, it becomes clear what Kant is attempting to convey in his ethics.

For Bordum (2002), understanding Kant's conception of duty is to distinguish it from the alternative uses of the concept such as social, religious and the common usage of the concept. Thus Kant's duty is an imperative which is a justification to a rational will with a normative force as opposed to an empirical force. So for Kant, there should be a formula that can validate statement and moral laws that can be understood as valid for all rational agents (Kant 1994). Again, Bordum (2002) further asserts that Kant's conception of in terms of imperatives is narrow as a result of the quest to elicit a concept that is universally accepted. Additionally, Varden (2010) observes that the whole of Kant's indicates that all moral actions must be based on a maxim that can be universalised and that we must do the right thing because it is our duty. An illustration is made of the case of the inquiring murderer that emphasises the dilemma of lying to save a life. Conceived this way then lying in the inquiring murderer case is seen as accomplishing two goals: firstly, it seems to repeat how one ought never to lie as the maxim of lying is not universalisable, and secondly, it cashes out the implications of this moral principle with regard to people's enforceable rights and duties against one another. 
Timmermann (2013) duty renders any conflicting inclinationbased consideration, whether immediate or long-term, normatively invalid. The obligatory act is objectively necessary; any other action is rationally impossible. This means that if duty really makes one action practically necessary one must consider all other actions illegitimate, not just those that are grounded in the sensuous side of human nature. Kant (2013) thus argues on conceptual grounds that of two contradictory commands only one can be one's duty. This then implies that duties cannot conflict. However, this conceptualisation is problematic especially when moral agents are clearly faced with some of the enumerated duties Kant himself gives. For Kant, moral agents have duty to keep promise and also duty to tell the truth. It will be normatively inconceivable to believe that such duties cannot conflict. Unless moral agents out to assume that acting in accordance with duty is a first come first served phenomenon where the first conceivable duty ought to be performed over any other which appears later. This does not adequately further solve the problem of conceptualisation as far as the impossibility of duties conflicting is concerned.

Guyer (2002) on his part asserts that Kant's argument is simply that since our conception of the moral worth of an action from duty implies that the performance of such an action must be independent of any and every impulse, immediate or mediate, that might give one a reason for conforming to any law. We note however that Kant (2013) recognizes that a rational agent even without philosophical instruction has means available to determine what ought to be done and stresses that what duty is, is plain of itself to everyone.

In contributing to the discourse on the nature of duty, Ackeren\& Martin Sticker (2015) assert that the content of moral 
demands can be either stringent, or lenient. On that note, stringent demand is that which requires great sacrifices. How stringent morality is thus depends on how the moral perspective or the moral point of view and its relation to interests is construed. In this vein, absolute adherence to duty is a stringent demand which admits of no exception for moral agents to find an escape routes to create excuses as justifications.

\section{Pragmatic Reflection on Kantian Duty}

Kant's ethics is called deontological because of the insistence that moral agents act for the sake of duty. Kant holds an absolute conception of duty whereby duty admits of no exception. We act on duty for the sake of duty. This conception is opposed to desires and reward that are consequentialist concepts. This is because Kant's deontology does not look at the role that desire and reward play in moral actions. In fact, these concepts do not play any part in action that has a moral content at all (Kant\& Schneewind, 2002). However, we see areas of harmonization between these concepts and Kant's concept of duty. We do this by modifying Kant's concept of duty that it is not to be necessarily absolute in the strictest sense. There are instances when duty admits exception. Also, in the performance of our duty, human desire and feeling play a major role. Thus there is the desire to perform one's duty and a reward of satisfaction after the performance of that duty.

For Larmore (1996) if the notion of right is replaced by that of good at the foundations of ethics, then the moral ideal will no longer be imperative, but rather attractive. His point was that ethical value may be defined either as what is binding upon an agent, whatever may be his wants or desires, or as what an agent would in fact want if he were sufficiently informed about what he 
desires. In the first view, the notion of right is fundamental, in the second the notion of good. We explicitly share Williams' (1981) view that moral requirements give reasons for actions and since all reasons are, to a large extent, internal and dependent on desires, moral requirements are not wholly categorical but also dependent on desires. We infer from Williams (1981) that whatever is a motivation factor for a moral agent to act is what gives the agent the reason to act. He therefore, observes that for reasons to be able to motivate an action it must be able to implicate a desire or be aided by a pre-existing desire. Generally, moral requirements give reasons for us to act when the motivating factor is our desires.

Yang (2006), however, thinks otherwise, he believes that there is a condition which the categorical imperative satisfies that cannot make moral requirements be based on desires and this is the intrinsic-end condition. The condition states that a categorical imperative represents an action that is good in itself or good apart from the relation to a further end (Yang, 2006). This view is different from saying that a moral requirement is independent of desires. Kant himself observed that "if an action is represented as good in itself and therefore as necessary, then the imperative is categorical" (Kant, 1956). Yang (2006) thinks this is different because it is possible for a moral requirement to be independent of desires but be good as a means. But we may assess whether it cannot also be possible that an action that requires our feelings can also have the intrinsic-end condition. The intrinsic-end condition is a necessary condition for a duty but seldom analysed whether there can be instances when the intrinsic-end can also apply to actions emanating from our desires. Also, as to whether desire is not responsible for directing us towards what has the intrinsic-end. We wish to point out that intrinsic-end, sometimes, meets with desire and duty. For instance, I have the desire to be educated. I pursue 
my education and pay my fees because I feel that it is my duty to sponsor myself and also because, education for me is categorical, good in-itself and conforms to a priori rational moral principle of self-improvement. Again, I may want to be educated so that I will be employable and get a higher standard of living. In both instances, duty, intrinsic-end and the categorical have the tendency of together motivating an action.

The ambition is not to deny the dutiful nature of moral requirements. Even when it is denied that moral requirements are not our duty, it seems difficult to deny that desires do not play any major role in acting on what is moral. Imagine a world when one does not desire anything, including the desire to act morally, such a world would be a 'dead' one. Morality is not always what our duty to do is; moral agents sometimes need to apply our rational ability of choice in deciding what is moral. According to Prichard (2002), to distinguish between the good and the right in terms of the directives they yield, the good attracts our desires while the right tells us what we must do. Further, Gaus (2001), asserts that right action is a function of the maxim on which it is based rather than the results which it yields.

There seem to be an error that Kant (1959) did not pay attention to and this is the over generalization view that he had on desire. He seems to think or assume that all desire was desire for pleasure; and in talking of pleasure he also saw pleasure in the realm of sensual and bodily desires, to a large extent. He does not seem to have considered intellectual satisfaction as well as pleasures connected to the development of the mind in a positive sense. In this sense, Hazlitt (1964) thinks that there is a psychological basis for Kant's error. He thus says;

... when we perform a beneficent act out of love or completely spontaneous benevolence we are not conscious 
of doing our duty. It is only when we have a disinclination toward an act that nevertheless "force" ourselves to do it, in the conviction that it is our duty, that we are conscious of doing our duty ... (Hazlitt, 1964:25)

Thus, Kant (1959) seems to have used this human behaviour to have proposed that it is always our duty to do what is right whether we like it or not. That is to say, it is always our duty to do our duty. One can agree with Kant that it is, in fact, our duty to do what is right, but seem to differ on the further proposition that it is sometimes necessary to force ourselves to perform our duties against other desires and such instances does not mean that these are the only occasions that we act morally. We, in other words, mean to say that we recognize the need to constantly remind ourselves, sometimes, about what our duties are and, even, sometimes perform them against our wish, but Kant (1959) seems to hold that this is when our actions become moral. However, we put across that it is not the only occasion that our actions become moral. If we strictly side with Kant (1959), then, what will we say of a man who spontaneously acts out of the good will towards another man or who has developed the habit of acting out of duty and morally from infancy. What will happen to such a person is that he will act that way habitually and spontaneously, rather than from a conscious sense of duty. What Kant (1959)should have taken such instances into consideration and realized that moral lives become complex by the day and so a seeming restrictive thought might not be acceptable in all situations.

The question of reward in performing an action is, in fact, part of the natural composition of man. In our daily affairs, humans are driven by reward to even perform their duty effectively. The idea of expecting a satisfactory return after an 
action is done is what we might term as a reward. In this working definition of what a reward is, we realise that reward is not only material returns of an action but even the level of understanding or acceptance that an action produces. The import here is that, even, when we perform our duty, we consciously or unconsciously look out for a reward after the performance of that duty. A reward of satisfaction that we have performed what is morally required of us or that our duty has produced good consequences. For instance, presenting a birthday gift to your partner in anticipation of the happiness you derive from making your partner happy. This situation, we believe, does not make an action immoral. Thus the anticipation of a reward sometimes motivates us into acting morally, in Kant's case, doing what duty requires.

Further analysis of Kant's work reveals other difficulties with his position. His position tacitly asserts that moral agents should act purely out of the motive of duty for such act to have a moral content. This is because, in some human situations, we seem to often perform some actions we might deem noble or selfsacrificing out of love other than out of duty. As a result, we naturally praise a father who performs what we deem is his duty, namely; taking care of his children out of love. In this regard, we blame a father who performs his duty to his children with repugnance. However, humans are inclined to perform their duty better when they see the joy, and develop the desire, to perform such a duty. Indeed, it even makes the performance of duties in a better manner. The desirable feeling that is developed towards the performance of duty becomes a motivation to perform duty without repugnance. This illustrates the role of desire in the performance of duty. Also, an action that is motivated by both duty and desire carry a moral worth, since it seems to be in line with some human situations. Humans do not necessarily act out of 
the motive of duty alone at all times but sometimes act with the aid of desire. Here, we ascribe the property of intrinsic value to some forms of desires just as Kant (1959) ascribed to duty.

Duty in morality, therefore, is a matter of necessity. Moral agents, so far as we are imperfect need to be compelled by reason to act in accordance with the moral law. The question of what is my duty and who sanctions duty gives a different form to the argument. Duty is a moral demand which are sometimes instinctively innate but sanctioned by society and the individual. Its origin has been an issue of diverse views. For some moral philosophers, it is a God-given command to act in a certain way, an instinctive feeling embedded in man since the day of his birth. Some, however, ascribe what counts as duty solely on what the society commands as well as what the individual adheres to. It is observed that, the use of conscience is a guiding principle to what duty is. That is, when we fail to perform what duty requires, our conscience sometimes becomes the best assessor of the morality or otherwise of that action. This force drives men to perform their duty in as far as they are rational.

We see of Kant (1959) that he was concerned with setting up a framework that would operate against plurality of values and maxims. This strict mission also accounts for the non-simplistic and rigid interpretation of what is moral. We sometimes allow for plurality of moral values that have the tendency of moral praiseworthiness. There are duties like preservation of one's life, development of one's talent, etc, which count as duty to oneself. A possible inference is that there are instances when a person's duty to develop his talent is a duty he has towards his family, friends and society other than himself. But this view generally defeats the critics' claim that Kant (1959)does not pay attention to the division of duty to oneself and duty to others. 
A person has a duty to himself such as a duty to even keep and promote his maxims. Thus, if it is acceptable that we have duties to others, then, we also have duties to ourselves. Duty to develop one's talent is a duty to family and society and not oneself can be given a further interpretation. It is legitimate to claim that a person has a duty to develop himself. However, society and family come in when we consider the long and short-term effects of such duties. Again, duties can be contractual and still hold applicability. For instance, my duty to honour my parents depends on them doing the right thing. If my father, for instance, decides to kill an innocent person, I am not compelled to hide the truth just because I must honour my parents or protect my family. Thus, to have a duty towards someone, sometimes, assumes a contractual character.

Kant claims that the ultimate end of every rational being is to promote the happiness of others for the sake of their happiness. Kant observes that humanity now could in no doubt subsist if everybody contributed nothing to the happiness of others but at the same time refrained from deliberately impairing their happiness. This is however, merely to agree negatively and not positively with humanity as an end in itself unless every one endeavours also, so far as in him lies, to further the ends of others (Kant, 1956).This supports the view that Kant sees the moral law as being altruistic in nature. This allows for an integration of utilitarianism and Kant since they all seem to share the view that man is a social animal and as a result every action he takes one way or the other affects others as well. Therefore humanised deontology opines that altruism in morality is, indeed, an important aspect in determining a morally commendable action. Thus, both Kant's deontology and utilitarianism all proceed from one platform and complement each other in this sense. If Kant accepts that ethics has an empirical 
dimension, then, he can be allowed to appreciate the role that happiness plays. Our view is that ethics is both a priori and $a$ posteriori and it is important to develop a synthesis that blends the two. In this sense, qualitative happiness can be categorical.

\section{Conclusion}

Kant's idea of acting in accordance with duty emanates from his idea of the good will. He emphasises on the good will which according to him must control every action. As a result we might act in accordance with what duty requires but if it is not from the good will, the action might not be moral. In this sense, the pivot of Kant's deontological ethics is on duty and its reflection on the good will. Thus, a moral act is one that is done in accordance with the good will. The difficulty, then, arises when we ask how we know an action arises out of the good will. It is possible for one to act in a good way but not out of the good will, and we seldom can know the motivating force behind the action. Kant talks about acting on the good will out of duty and for no other reason.

The satisfaction of the reasoning or thinking side oh humans is when our action is based on the good will and duty. When the moral law applied in a legalistic and formalistic manner, it satisfies the thinking and rational composition of humans. Kant gave primacy to reason alone, negating the possibility of desires in deciding what is moral, but we wish to say that desires play a role in deciding what is good. We recognise the superiority of reason when deciding which action is right, but desire's role is primary. By man's nature we sometimes perform our moral duty out of the desire to do so. We desire to be generous, honest, etc. This does not rule out the fact that we also act out of duty for its own sake, but even when acting out of duty, man does not neglect the role of desire and consequences. Many people give alms out of pity for 
the sick, others look after their children out of love, some choose a career and work dedicatedly out of interest, and people choose to lecture because they feel the joy to do so. Practically, man acts, chooses certain careers or takes certain decisions out of desire. This does not leave out the role reason plays. Acceptance of anchoring moral assessment on duty and as a result a priori does not negate the additional recognition of desire or reward which can be considered as a posteriori.

Kow Kwegya Amissah Abraham

Department of Classics and Philosophy University of Cape Coast, Ghana kow.abraham@ucc.edu.gh 


\section{References}

Birsch, D. (2002): Philosophical issues: A brief introduction. New York: McGraw-Hill.

Bordum, A. (2002). The Categorical Imperative Analyzing Immanuel Kant's Grounding for A Metaphysics of Morals (No. 4/2002).

Cooke, V.M. S.J. (1974): The development of Kant's view of ethics. International philosophical quarterly. Vol. XIV, No. 1

Field, G.C. (1966): Moral theory. London: Methuen Co. Ltd.

Gaus, G. F. (2001). What is deontology? Part two: Reasons to act. The Journal of Value Inquiry, 35(2), 179-193.

Guyer, P. (2002). The Derivation of the Categorical Imperative:

Kant's Correction for a Fatal Flaw. The Harvard Review of Philosophy, 10(1), 64-80.

Hazlitt, H. (1964): The Foundations of morality. London: D. Van Nostrand Company, Inc.

Kant, I. (1959): Critique of practical reason. Abbott (trans.). London: Longmans, Green and Co. Ltd.

Kant, I. (1959): Groundwork of the metaphysics of morals. T. K. Abbott (trans.). London: Longmans, Green and Co. Ltd.

Kant, I. (1994). The metaphics of morals. Hackett, Indianapolis/Cambridge (trans. James Ellington).

Kant, I. (1998). Groundwork of the Metaphysics of Morals (1785) Cambridge.

Kant, I. (2013). Moral Law: Groundwork of the Metaphysics of Morals. Routledge.

Kant, I., \& Schneewind, J. B. (2002). Groundwork for the Metaphysics of Morals. Yale University Press.

Kempt, J. (1968): The philosophy of Kant. London: Oxford University Press. 
Korsgaard, C. M. (2009). Natural Motives and the Motive of Duty:

Hume and Kant on Our Duties to Others.

Larmore, C. (1996). The morals of modernity. Cambridge University Press.

Lillie,W.(1966): An Introduction to Ethics. New York: Barnes and Noble.

Louden, R. (2000): Kant's impure ethics. New York: Oxford University Press.

Miller, Ed. L (1995): Questions that matter: an invitation to philosophy. New York: McGraw-Hill Companies, Inc.

Ozumba, G.O (2002) A course text on Ethics

Paton, H.J. (1964): The moral law. London: Hutchinson University Library.

Prichard, H. A. (2002). Moral writings (Vol. 3). Clarendon Press.

Ross, W. D. (1975): The right and the good. Mary Gregor, (ed). Oxford: Oxford University Press.

Ross, W.D. (1962): Kant's ethical theory. Oxford: Clarendon Press.

Sandel, M. J. (2010). Justice: What's the right thing to do? Macmillan.

Shirk, E. (1965): The ethical dimension: an approach to the philosophy of values and valuing. New York: Meredith Publishing Company.

Timmermann, J. (2013). Kantian dilemmas? Moral conflict in Kant's ethical theory.

Urmson, J.O. (1967): The interpretation of the moral philosophy of J.S. Mill in Theories of ethics. Foot, (ed). Oxford: Oxford University Press.

vanAckeren, M., \& Sticker, M. (2015). Kant and moral demandingness. Ethical Theory and Moral Practice, 18(1), 75-89. 
Varden, H. (2010). Kant and lying to the murderer at the door... One more time: Kant's legal philosophy and lies to murderers and Nazis.

Von Wright, G.H. (1963): The varieties of goodness. London: Routledge and Kegan Paul.

Williams, B. (1972): Morality. Cambridge: Cambridge University Press.

Williams, B. (1981): Internal and external reasons.'In Moral luck. Cambridge: Cambridge University Press.

Yang, X. (2006): Categorical imperatives, moral requirements and moral motivation. In The author journal. Oxford: Blackwell Publishing Inc.

Zink, S. (1962): The concept of ethics. London: Macmillan and Co. Ltd 